NBER WORKING PAPER SERIES

\title{
THE SOURCE OF HISTORICAL ECONOMIC FLUCTUATIONS: AN ANALYSIS USING LONG-RUN RESTRICTIONS
}

\author{
Neville Francis \\ Valerie A. Ramey \\ Working Paper 10631 \\ http://www.nber.org/papers/w10631
NATIONAL BUREAU OF ECONOMIC RESEARCH 1050 Massachusetts Avenue
Cambridge, MA 02138
July 2004

Valerie Ramey gratefully acknowledges support from National Science Foundation grant National Science Foundation grant \# 0213089. We are grateful to Darran Tucker for providing us the UK data and to Susanto Basu, Garey Ramey and Harald Uhlig for helpful comments. The views expressed herein are those of the author(s) and not necessarily those of the National Bureau of Economic Research.

(C2004 by Neville Francis and Valerie A. Ramey. All rights reserved. Short sections of text, not to exceed two paragraphs, may be quoted without explicit permission provided that full credit, including $\mathbb{C}$ notice, is given to the source. 
The Source of Historical Economic Fluctuations: An Analysis using Long-Run Restrictions Neville Francis and Valerie A. Ramey

NBER Working Paper No. 10631

July 2004

JEL No. E2, E3

\section{$\underline{\text { ABSTRACT }}$}

This paper investigates the source of historical fluctuations in annual US data extending back to the late 19th century. Long-run identifying restrictions are used to decompose productivity, hours, and output into technology shocks and non-technology shocks. A variety of models with differing auxiliary assumptions are investigated. The preferred model suggests that the Great Depression was a period in which both types of shocks were very negative. On the other hand, our estimates support the microeconomic evidence of historically large positive technology shocks from 1934 to 1936. Finally, both types of shocks are responsible for the reduction in the variance of output in the postWWII period.

Neville Francis

Department of Economics

Lehigh University

620 Taylor Street

Bethlehem, PA 18105

nef2@1ehigh.edu

Valerie A. Ramey

Department of Economics, 0508

University of California, San Diego

9500 Gilman Drive

La Jolla, CA 92093-0508

vramey@ucsd.edu 


\section{Introduction}

There has been a recent surge in the number of papers studying real business cycles and the role that technology shocks plays in generating cyclical movements in macroeconomic data. Such renewed interest in technology-driven business cycles has been fueled by the finding of recent empirical studies that labor input falls, at least in the short run, in response to a positive technology shock - see Shea (1998), Galí (1999), Basu, Fernald and Kimball (2004) and Francis and Ramey (2003). These results have generated a good deal of discussion because they raise fundamental questions about the empirical relevance of the technology-driven real business cycle hypothesis.

The goal of this paper is to analyze the historical role played by technology shocks in the US by studying the fluctuations in data extending back to the $19^{\text {th }}$ century. Our approach is to identify technology shocks using long-run restrictions as in Blanchard and Quah (1989) and Galí (1999). It seems particularly appropriate to use long-run restrictions for identification in truly long-run data. We carry out our analysis for the entire sample period and for two subsamples of the data, the pre- and post-WWII eras. Our subsample results are then compared to see if there have been any changes in the nature of technology shocks or in their transmission mechanism. To check the robustness of our results, we identify technology shocks using various assumptions about the source of nonstationarity in the data. The time series properties of the data is a concern at the heart of the debate concerning the validity of the standard RBC hypothesis. ${ }^{1}$

We construct a new series of hours per capita that adjusts for demographic and social trends. With this measure, the results for the post-WWII period are quite similar whether one

\footnotetext{
${ }^{1}$ Several economists have expressed concern that this new finding could be a direct result of the stationarity assumptions made of the time series used in the structural vector autoregressions; see Christiano, Eichenbaum and Vigfusson (2003).
} 
assumes hours are stationary, trend stationary or nonstationary. The results differ across specifications in the early period. Only the specification that assumes a unit root in hours produces technology shocks that are not Granger-caused by monetary and government spending variables.

The preferred unit root specification gives an interesting account of the historical sources of fluctuations. Technology shocks are much more important for the forecast variance of output and hours in the early period than in the later period. The Great Depression was a time in which both types of shocks were very negative for several years. The period immediately after the Great Depression was a period of extraordinarily high positive technology shocks. Finally, the variance of both types of shocks decreased dramatically in the post-WWII period.

\section{Overview of the US Historical Data}

This section presents an overview of the US data as a preliminary step to estimation of the structural VAR. The data are annual for the time period 1889 - 2002. The principal variables studied are labor productivity and hours for the private business sector. Private output is constructed from these two variables. In augmented models and in additional tests, data on consumption, investment, government spending, the price level and money are also used.

Data for the early part of the sample come from John W. Kendrick's Productivity Trends in the United States (1961), Historical Statistics, Balke and Gordon (1989), and Anderson (2002). Data for the later part of the sample are obtained from the Bureau of Labor Statistics (BLS), the BEA, the Economic Report of the President, and the Federal Reserve. The appendix provides a detailed description of all the data and their sources. 
Figure 1A shows a graph of the logarithm of output per hour in the private sector. It is difficult to distinguish the cyclical movements in output per hour because the overall upward trend is so strong. A slowdown in the rate of growth beginning in the early 1970s is apparent from the graph, however. Figure 1B shows the growth rate of output per hour. The most noteworthy feature of this graph is the difference in volatility between the pre- and post-WWII period.

The only assumption required for our identification technique is that output per hour have a unit root. As Table 1, Panel A shows, one cannot reject a unit root in labor productivity against either of the three alternative hypotheses. This result also holds in the pre- and post-WWII subperiods. On the other hand, further ADF tests (not shown) overwhelmingly reject a second unit root. Thus, the data support the key identifying assumption.

Consider now the time series properties of hours per capita. The nature of this series in the post-WWII period has been the source of much recent controversy because different assumptions can lead to different results in structural VARs (e.g. Christiano, Eichenbaum, and Vigfusson (2003), Francis and Ramey (2003), Fernald (2004), Galí (2004)). Figure 2A plots the standard measure used - it divides total private hours by the population 16 and older. This measure of hours per capita clearly has a trend during the 114 years of the sample, falling by 37 percent from 1889 to 2002. Table 1, Panel B shows that the only case in which one can reject a unit root is in the early sample, in favor of the alternative with a quadratic trend.

Our investigations reveal that the main source of the trend in this measure is not taxes and regulations, as some have argued (e.g. Mulligan (2002)). Rather, most of the trend is due to changing demographics, school enrollments and the growth of government employment. Consider an alternative series, shown in Figure 2B. This series adjusts for three important trends 
over the sample: (1) the growing fraction of workers in government; (2) the changing fraction of population that is too young to work or is in school; and (3) the growing fraction of retirement age population, 65 and over. This series consists of dividing total private hours by total population minus (1) the full-time equivalent number of employees working in government; (2) the population aged $0-4$; (3) the number of individuals enrolled in school; and (4) the population aged 65 and over. ${ }^{2}$

The demographically adjusted series in Figure 2B paints a very different picture. Average hours were still higher at the start of the $20^{\text {th }}$ century than at the end, but the difference is much smaller. Hours per capita in the year 2000 were only 3.5 percent lower than they were in 1900. Thus, most of the trend in the standard series stems from slow-moving demographic, government employment, and educational trends.

Figure 3 shows graphs of the various series that were used to adjust population. The fraction of the population employed by the government shows spikes during the two world wars, but also is higher in the post-WWII period than in the pre-WWI period. The fraction of the population age 65 and older shows a steady-upward trend. ${ }^{3}$ Both graphs on the right hand side show the effects of the baby boom, which started in the 1950s. After the baby boom graduates, the fraction of the population in school falls, but remains significantly higher in the late century than in the early century. Years spent in school have increased significantly, both because of increased government subsidies and because of the rising returns to education. The low

\footnotetext{
${ }^{2}$ We also created a series that added total government hours to the numerator rather than subtracting government employment from the denominator. This series is very close to the one presented.

${ }^{3}$ Moreover, the labor force participation rate of this age segment has decreased over time relative to the population age 16 and older. Adjusting for changes in the differential rate of labor force participation does not noticeably change in the series in Figure 2B.
} 
frequency movements in these series lead to low frequency movements in unadjusted hours per capita.

Panel C of Table 1 shows the results of unit root tests on the demographically adjusted hours series. The p-value of a unit root test against the alternative of stationarity is 0.057 for the entire period. On the other hand, in the subperiods, one can reject a unit root only against a quadratic trend in the pre-WWII subperiod.

Since the unit root results do not give a clear picture, we initially consider three possible specifications: hours in levels, deterministic trend in hours, and a unit root in hours. The reason for looking at trend specifications is that there are clearly still some low frequency movements in our adjusted hours per capita. For example, hours per capita in the 41 years from 1889-1929 never cross the mean of hours per capita in the years 56 years 1947-2002 and vice versa. It is likely that other demographic influences that we have not measured account for the remaining low frequency movements as well. To account for the unmeasured slow-moving demographic forces, we subtract a quartic trend from our measure of hours. Since the purpose of the trend is to capture slow-moving demographic forces rather than business cycle forces, we estimate the trend omitting the large outliers from 1930-1946. Figures 4A and 4B show the trend and its effect. The fitted trend is very similar to what one would obtain using a Hodrick-Prescott filter with a very high value of the $\lambda$ parameter (the parameter that penalizes changes in the estimated trend), such as 5000 rather than the standard 100 for annual data. The implied cyclical movements, shown in Figure 4B, line up well with official NBER dates. Hours are generally below trend during official recessions and above trend during expansions. 


\section{Estimated Responses to a Technology Shock}

\section{A. Econometric Methodology}

The baseline specification is a bivariate model of labor productivity and labor input similar to the benchmark models of Galí (1999) and Francis and Ramey (2003). Under this specification technology is identified as the only shock that can have permanent effects on labor productivity. This assumption is less restrictive than Blanchard and Quah's (1989) identification assumption since it allows non-technology shocks, such as changes in government spending, to have permanent effects on output. On the other hand, if changes in distortionary taxes affect the capital-output ratio, and hence labor productivity, this identification scheme classifies them as technology shocks. For example, a cut in capital tax rates that permanently raised labor productivity would be called a "technology shock" in our model. ${ }^{4}$

Consider the system in which hours are assumed to be stationary or trend stationary:

$$
\left[\begin{array}{l}
\Delta x_{t} \\
n_{t}
\end{array}\right]=\left[\begin{array}{ll}
C^{11}(L) & C^{12}(L) \\
C^{21}(L) & C^{22}(L)
\end{array}\right]\left[\begin{array}{l}
\varepsilon_{t}^{z} \\
\varepsilon_{t}^{m}
\end{array}\right]
$$

$x_{t}$ denotes the $\log$ of labor productivity, $n_{t}$ denotes the log of labor input (or deterministically detrended $\log$ of labor input), $\varepsilon^{z}$ denotes the technology shock, and $\varepsilon^{m}$ denotes the nontechnology shock. $\mathrm{C}(\mathrm{L})$ is a polynomial in the lag operator. We maintain the usual assumption that $\varepsilon^{z}$ and $\varepsilon^{m}$ are orthogonal. Our assumption identifying the technology shock implies that

\footnotetext{
${ }^{4}$ Francis and Ramey (2003) and Gali (2004) rule out capital income taxes as an explanation for the technology shock results. Francis and Ramey found that their results were robust to the inclusion of capital income tax in their estimations while Gali found that innovations to such taxes were uncorrelated with his identified technology shocks.
} 
$C^{12}(1)=0$, which restricts the unit root in productivity to originate solely in the technology shock.

Another way to think about this restriction is through the estimation method suggested by Shapiro and Watson (1988). Consider the following system of equations:

$$
\begin{aligned}
& \Delta x_{t}=\sum_{j=1}^{p} \beta_{x x, j} \Delta x_{t-j}+\sum_{j=0}^{p-1} \beta_{x n, j} \Delta n_{t-j}+\varepsilon_{t}^{z} . \\
& n_{t}=\sum_{j=1}^{p} \beta_{n n, j} n_{t-j}+\sum_{j=1}^{p} \beta_{n x, j} \Delta x_{t-j}+\theta \varepsilon_{t}^{z}+\varepsilon_{t}^{m} .
\end{aligned}
$$

As discussed by Shapiro and Watson (1988), imposing the long-run restriction is equivalent to restricting the other variables to enter the equation in differences. Because the current value of $\Delta n_{t}$ will be correlated with $\varepsilon_{t}^{z}$ in the first equation, instrumental variables must be used to estimate the equation. Using lags one through $\mathrm{p}$ of $\Delta x_{t}$ and $n_{t}$ as instruments for the first equation yields estimates that are identical to those obtained using matrix methods. ${ }^{5}$ The baseline specification uses two annual lags of each variable.

The second shock to the system, $\varepsilon_{t}^{m}$, is identified by including the estimated residual from the first equation in the second equation, along with the standard lags of the variables, as shown in equation (1b). The estimated residual from this equation, $\varepsilon_{t}^{m}$, is identified as the "nontechnology" shock.

If, instead, hours have a unit root, the system to be estimated is as follows:

\footnotetext{
${ }^{5}$ See the appendix of Francis, Owyang and Theodorou (2003) for an explicit derivation of the equivalence of the Shapiro-Watson and matrix methods.
} 


$$
\begin{aligned}
& \Delta x_{t}=\sum_{j=1}^{p} \beta_{x x, j} \Delta x_{t-j}+\sum_{j=0}^{p-1} \beta_{x n, j} \Delta^{2} n_{t-j}+\varepsilon_{t}^{z} . \\
& \Delta n_{t}=\sum_{j=1}^{p} \beta_{n n, j} \Delta n_{t-j}+\sum_{j=1}^{p} \beta_{n x, j} \Delta x_{t-j}+\theta \varepsilon_{t}^{z}+\varepsilon_{t}^{m} .
\end{aligned}
$$

In this system, the hours must be double-difference in the first equation in order to impose the long-run restrictions. The second equation is run in the first-difference of hours.

For all specifications, both equations are estimated jointly using GMM. The estimated variance-covariance matrix takes into account the fact that the technology shock that appears as a regressor in the hours equation is estimated from the first equation. It is also robust to heteroscedasticity, an important feature in light of the evidence presented below that the variance

of the shocks changes over time. The standard error bands for the impulse response functions are derived by generating random vectors from a multivariate normal distribution with mean equal to the coefficient estimates and variance-covariance matrix equal to the estimated one, and then calculating the impulse response functions.

\section{B. Impulse Response Functions for Three Difference Specifications}

The results from estimating the model with hours in levels, detrended with a quartic trend, and with a unit root are shown in Figure 5. Recall that productivity is assumed to have a unit root in all specifications. The first column of Figure 5 shows the effect of a unit technology shock and the second column shows the effect of a unit "non-technology" shock.

Consider first the results in the first column. In all three cases, a positive technology shock leads to a permanent increase in productivity, with some initial overshooting. The unit root and deterministic trend specifications have very similar effects, while the response under the 
levels specification is somewhat smaller. The estimates are all significantly different from zero at the 10 percent level.

The response of hours differs significantly across specifications. In the levels specification and the deterministic trend specification, hours fall temporarily in response to a positive technology shock. This result is consistent with the findings of Galí (1999) and FrancisRamey (2003) and others for the post-World War II period. Christiano, Eichenbaum and Vigfusson (2003) find the opposite result for the post-war period when they assume that hours per capita are stationary. Some have argued that their measure of hours per capita, which divides by the total population age 16 and over, is not stationary. Our measure, which demographically adjusts the population, produces a negative response. In contrast, the unit root specification that uses our measure predicts a significant increase in hours. As we shall see below, this result does not hold over the entire sample.

All three specifications show a permanent rise in output in response to the technology shock, although the levels specification shows output actually declining for a few years before becoming positive. This initial negative response of output also appears in Basu, Fernald and Kimball (2004), who use annual data as well. ${ }^{6}$

The second column of Figure 5 shows the responses to a "non-technology" shock. This shock includes any shock that does not have a permanent effect on labor productivity. The levels and deterministic trend specifications show this type of shock raising productivity temporarily, while the unit root specification shows a very transitory fall in productivity.

Hours and output behave quite similarly across specifications in the first few years after the non-technology shock. The key difference is that the effects on hours and output are

\footnotetext{
${ }^{6}$ Analyses using annual data often find an initial decline in variables such as output and investment, whereas those using quarterly data typically do not.
} 
permanent in the unit root specification whereas the effects are transitory in the two other specifications.

How stable are these estimates across time and to what extent are they accounted for by the dramatic movements of World War II? To answer these questions, we re-estimate the model for the subperiods $1892-1940$ and $1948-2002$. Breaking the sample in this way is supported by structural break tests. When we estimate a model with an unknown break that affects all coefficients and the variance, the log likelihood reaches a maximum for both the productivity and hours equations in the late 1940s, typically between 1948 and 1949.

Figures $6 \mathrm{~A}$ and $6 \mathrm{~B}$ show the results for the various specifications across the two samples. Figure 6A shows the effects of a unit technology shock. Consider first the graphs in the second column, which shows the results for the models estimated from 1949-2002. The effects of a technology shock are quite similar across specifications. This result stands in contrast to the results from the literature that use hours divided by population age 16 and over. There, the levels specification gives very different results from the unit root and deterministic trend specifications. With our measure, all specifications give very similar results. In particular, all three measures show hours declining for at least one year in response to a technology shock.

The story is different in the early period, shown in the first column of Figure 6A. The effects of a technology shock differ across specifications in the early period, with the most positive effects coming from the unit root specification. Hours fall temporarily in the levels and trend specifications, while they rise permanently in the unit root specification. The results are in fact similar to those estimated over the entire sample, which is not surprising since the early period has more dramatic movements in the variables. The levels specification implies that a 
positive technology shock depresses output for a number of years in the early period, though the estimates are not significant.

Within each specification, the most notable change in a response across the pre- and postWWII periods is the response of hours in the unit root specification. The response to a technology shock is strongly positive in the early period, but temporarily negative in the later period. The potential source for this structural break is discussed in Section D below.

Figure 6B shows the effects of a non-technology shock across periods. The levels and deterministic trend specifications suggest that the effects of nontechnology shocks are somewhat less persistent in the later period than in the earlier period. The first-difference specification shows that the effects on hours and output are permanent in both periods.

Table 2 compares the estimated technology shocks across specifications and time periods. The correlation between the technology shocks estimated under the assumption of a unit root and the other specifications is quite low in the pre-WWII period, between 0.12 and 0.42 . In contrast, the technology shocks from the levels and deterministic trend specifications are highly correlated with each other in the early period. In the post-WWII period, the technology shocks have a very high correlation across specifications, above 0.87. The correlations for the non-technology shock (which are not shown) have a very similar pattern across specifications for both time periods.

The bottom panel of Table 2 shows the relative standard deviations of the technology and non-technology shocks. The levels specification suggests that the standard deviation of the technology shock is 60 percent higher than that of the non-technology shock in the early period, whereas the quartic and unit root specifications suggest that they are about equal. In the late 
period, all three specifications indicate that the standard deviation of the technology shock is between 60 and 70 percent of the nontechnology shock.

\section{Which Specification is Most Valid?}

For the purposes of analyzing the source of shocks for the post-WWII period, all three specifications give similar answers to most questions. The impulse response functions are similar at short-horizons and the shocks identified are highly correlated across specifications. The only difference is the permanent effect of non-technology shocks on output and hours in the unit root specification. In contrast, the answers for the pre-WWII period depend very much on which specification one uses.

We assess the validity of each specification by subjecting the estimated shocks to an Evans-type test. As argued by Evans (1992), technology shocks should not be Granger-caused by nontechnology variables such as government spending and monetary variables (Granger (1969)). Evans cast doubt on the use of the Solow residual as a measure of technology shocks by showing that monetary variables and government spending Granger-caused the Solow residual. Thus, an additional means to test whether the identified shocks are really technology shocks is to test whether they are Granger-caused by these types of variables.

For each subperiod, we regressed the estimated shocks on two lags each of the growth rates of per capita government spending, money, and prices. (See the data appendix for details on these variables.) We then tested whether these variables Granger-caused the technology shock. The results are reported in Table 3.

The results indicate that only the technology shock estimated under the assumption of a unit root passes the test. In neither time period do the nominal and government variables 
Granger-cause the technology shock as estimated by the unit root specification. In contrast, the p-values are very low for both the levels and detrended specifications in the early period. In fact, government spending and the nominal variables explain between 34 and 40 percent of the variance of the "technology" shocks estimated with these specifications. The variables have more explanatory power for the technology shock than the non-technology shock. In contrast, the variables explain little of the technology shock estimated with the unit root specification, but explain 38 percent of variance of the non-technology shocks from this specification. All pvalues for the Granger causality tests on the technology shocks are above 0.1 in the late period. Recall that this is the period where all three specifications gave similar results.

To summarize, the Evans-type tests favor the unit root specification because it is the only specification whose estimated technology shocks are not Granger-caused by monetary and government spending variables in either period.

Another reason to favor the unit root specification is provided by Fernald (2004). In post-WWII data, Fernald finds that the results of the levels specification are sensitive to low frequency movements in the hours and mean productivity growth. In particular, Christiano, Eichenbaum and Vigfusson's (2003) finding that technology shocks raise hours reverses signs if one allows for statistically-supported breaks in mean productivity growth. On the other hand, the unit root specification is robust to these low frequency movements.

Based on the Granger-causality results above and Fernald's findings, we will use the unit root specification for the analysis in the remainder of the paper. The appendix shows some of the results with the quartically detrended data. Because of the evidence for a break in the late 1940s, we will continue to estimate the model separately over the two samples. 
We also subject the unit root specification to two more robustness checks. First, we increase the number of lags to four years and re-estimate the models. The additional lags are not significant and the results from this specification are similar to those from the model with only two annual lags. Second, we augment the system with consumption and investment. Both consumption and investment appear to have unit roots, and do not exhibit cointegration with each other or with productivity over the sample. Thus, both appear as double-differences in the productivity equation. This system gives similar results for the effects of the shocks on productivity, hours, and output. Consumption and investment rise permanently in response to both technology and nontechnology shocks in both sample periods. In the post-WWII period, the initial impact on investment is negative and then becomes positive.

\section{Discussion of the Impulse Response Functions from the Unit Root Specification}

Before proceeding to an analysis of the shocks, we discuss two aspects of the impulse response functions for the unit root specification that raise questions. Both concern the effect of a technology shock, shown in Figure 6A.

The first question raised by these estimates is why the response of hours to a technology shock changes so dramatically from the pre-WWII period to the post-WWII period. We begin by investigating whether the Great Depression or WWI is the key source of this behavior. When the model is estimated from 1892 to 1929 , omitting the Great Depression, the patterns are similar, though muted. In particular, whereas hours climb to a permanent plateau around unity for the 1892-1940 sample, in the 1892-1929 sample hours rise to 0.27 on impact then fall to a plateau of 0.17 . None of the movements is significantly different from zero. When we estimate 
the model omitting the WWI years 1917-1920 (with the extra years omitted because of the lags in the regression), we find very similar results to those for the period 1892-1940.

Thus, it appears that there was structural change in the economy that was not just limited to the Great Depression or WWI. Why do hours rise in the early period but fall in the later period in response to a technology shock? Francis and Ramey (2003) show that real rigidities such as adjustment cost on investment and habit formation in consumption can produce a temporary negative response of hours to a technology shock. King and Wolman (1996) and Galí and Rabanal (2004) show how price and wage rigidities (with suitable monetary policy rules) can produce a negative response to hours. If one were to apply one of these explanations to our results, one would have to identify structural changes in real rigidities, price and wage rigidities or monetary policy.

A simpler explanation comes from applying the insights of Lindé (2003). Lindé uses a standard RBC model to show that if technology growth is slightly persistent, hours will temporarily fall in response to a positive technology shock. Hours fall temporarily after a technology shock because agents know that productivity will grow so that wages will be higher in the future. On the other hand, if there is no persistence in technology growth, hours will rise in response to a technology shock.

The sets of graphs for the unit root specification across the two time periods in Figure 6A look quite similar to the two simulations Lindé shows in Figure 2 of his paper. In particular, the early period looks like the case with no positive persistence in the growth rate of technology. Productivity and output actually overshoot their new levels in our data, hours rise, and output rises to close to its new level. In contrast, the later period looks like Lindé's simulation in which technology growth has positive persistence. Productivity and output rise more slowly and hours 
decline temporarily. Hours eventually become positive in Lindé's simulation, though not in our empirical results. Thus, the change in the impulse response for hours across the two periods can be explained using a very standard RBC model in which the productivity growth process displays the changes shown in our impulse response functions.

The second question raised by these graphs is the apparent permanent effect of a technology shock on hours in the early period. While not inconsistent with a general RBC model, this result is inconsistent with the standard specification of preferences in an RBC model. Because hours per capita have changed little relative to real wages over the century, most RBC models specify a utility function in which the wealth and substitution effects of a technology shock exactly cancel. The impulse response functions for the later period clearly suggest a transitory effect on hours, but not for the early period. Whatever shocks are leading to permanent increases in productivity in the early period are also leading to permanent increases in hours.

\section{The Source of Historical Fluctuations}

We are now ready to assess the roles of technology and nontechnology shocks in historical fluctuations based on our preferred specification, which assumes a unit root in hours. We begin by analyzing the importance of teach type of shock in the overall variance of productivity, output and hours. We then analyze the nature of the shocks over specific historical periods. 


\section{A. Variance Decomposition}

To determine which type of shock is important for the variance of the key variables, we perform a forecast error variance decomposition. The results are shown in Table 4 for each period. According to the unit root specification, technology shocks are the main source of the variance of productivity and output at all horizons in the early period. Technology shocks account for 33 percent of the variance of the forecast error of hours at the one-year horizon, rising to 46 percent by the 20 year horizon.

The story is different for the later period for hours and output. While technology shocks continue to account for the bulk of the variance of the forecast error of productivity, accounting for two-thirds of the variance of productivity at the one-year horizon and becoming more important with each year, they account for much less of the other two variables. Technology shocks account for 25 percent of the one-year forecast of hours, but then decline in importance. Of course, as the impulse response functions show, the technology-induced movements in hours in the later period are negatively correlated with output. The final column shows that technology shocks are unimportant for output at business cycle horizons. These results for the post-WWII period are consistent with those of other researchers who use unit root specifications, such as Galí and Rabanal (2004). ${ }^{7}$

\section{B. Patterns of Shocks}

It is also interesting to study the historical pattern of the two types of estimated shocks. For completeness, we use our estimates from the period 1892-1940 to produce shocks for the

\footnotetext{
${ }^{7}$ As the Appendix Table shows, the quartically detrended specification gives very different results relative to the unit root specification in the early period. In the detrended specification, technology shocks only account for 40 percent of the forecast error variance of productivity at the one-year horizon and 62 percent at the 10 year horizon.
} 
WWII period as well. The shocks are virtually the same as if we used the coefficients estimated from 1892-1948. The shocks from 1949 to 2002 are derived from the model estimated over the 1949-2002 sample.

While studying the shocks, it is important to keep two points of interpretation in mind. First, what we call a "technology shock" is any shock that has a permanent effect on labor productivity. While true technology shocks fit this definition, other shocks such as government policies that subsidize education also fit this definition. "Non-technology shocks" are any shocks that do not have permanent effects on labor productivity. Examples of these types of shocks are monetary policy shocks and military spending shocks. Second, what we call a "negative technology shock" is any technology shock that is lower than average. Since technology growth is generally positive, what we call a negative technology shock can in some cases simply be a positive shock that is lower than average.

Figure 7 shows the historical pattern of technology shocks and nontechnology shocks estimated with the unit root specification. The recession dates identified by the National Bureau of Economic Research (NBER) are shown in the shaded areas. Note that the technology shocks tend to be negative around recession dates during the early period, but not so much during the later period. The reverse is true of the non-technology shocks, which tend to be negative around recessions in the post-WWII period.

The three years during the early period with the most negative technology shocks are 1908,1914 , and 1932. It is interesting to note that all three of these dates are associated with problems in the financial system. A banking panic occurred in October 1907. 1914 marked the outbreak of WWI, which brought some financial difficulties. For example, the New York Stock

The hours and output numbers in the early period are similar to those for the unit root specification in the later period. 
Exchange had to be closed for a day (Friedman and Schwartz (1963)). Finally, the banking crises of the early 1930s are well-researched. We will discuss the behavior of shocks during the Great Depression in more detail below.

During the post-WWII period, the three years with the most negative shocks are 1959, 1974, and 1987. 1959 is associated with the steel strike, 1974 with the first oil crisis and the collapse of the exchange rate system, and 1987 with the stock market crash. (See Eckstein and Sinai (1986) for a chronology of the post-war events.) It is not clear, though, that there was a causal link between these events and the estimated shocks.

On the positive side, the estimates suggest that the period from the late teens to the mid 1920s was characterized by a long string of positive technology shocks. The most positive technology shocks occurred in 1934, 1935, 1936, and 1941 in the early period. During the later period, the most positive technology shocks occurred in 1950, 1958, and 1960. The 1960s was characterized by a long string of positive technology shocks. We will discuss several of these periods in more detail below.

The four most negative nontechnology shocks occur in 1919, 1921, 1938, and 1946. According to the estimates, there was also a series of large negative nontechnology shocks during the Great Depression. During the postwar period, the three most negative nontechnology shocks occurred in 1974, 1982, and 2001. The most positive nontechnology shocks during the early period were 1941-1943. During the later period, the most positive nontechnology shocks occurred in 1950, 1984, and 1989. 


\section{Historical Chronology}

We now study the pattern of shocks during prominent periods of history to ascertain the key driving forces for fluctuations. We continue to refer to the graphs of shocks in Figure 7.

\section{The Early 1900s}

During the period 1892 to the first WWI, it is clear that much of the volatility in the economy was due to the volatility of technology shocks rather than non-technology shocks. During this period there were a number of very positive technology shocks as well as a number of very negative technology shocks. As mentioned before, the two most negative technology shocks occurred during banking crises.

\section{The 1920s}

According to our estimates, the 1920 s began with a series of large negative nontechnology shocks in 1919-1921. These shocks were no doubt linked to the wind-down from WWI and the conduct of monetary policy (see Friedman and Schwartz's (1963) account of this period). On the other hand, from 1918 to 1926 , every year saw positive technology shocks, suggesting that this was a period of steady technological progress.

\section{The Great Depression}

The graphs in Figure 7 show that both types of shocks contributed to the Great Depression. Both technology and nontechnology shocks were slightly positive in 1929, and then became very negative in the early 1930s. 1933 finally saw a positive non-technology shock, perhaps owing to the increase in government spending, but the technology shock remained negative. Comparing this period to the early 1920 s, we see that had the technology shocks not 
been negative, the early 1930s would have been more similar in magnitude to the recession of the early $1920 \mathrm{~s}^{8}$

\section{4-1940}

Particularly interesting is the series of high estimated positive technology shocks in the second half of the 1930s. The notion of large positive technology shocks during the 1930s is at odds with the conventional wisdom. Recent work by Field (2003), however, argues that the 1930s was the most technologically progressive decade. He shows that productivity growth between 1929 and 1941 was higher on average than the period 1919-1929 and cites several micro studies on innovations.

In his study, Field does not distinguish 1929-1933 from 1934-1941 because he wants to compare years with similar unemployment rates. What the average hides is how impressive productivity growth was during 1934-1941. Our calculations show that labor productivity growth was -1.61 per year from 1929-1933 but was 4.55 percent per year from 1933 to 1941. This rate is substantially higher than the 2.36 percent per year rate of growth from 1919 to 1929 . Thus, productivity growth during the second period was exceptionally high.

Microeconomic studies of innovations support the notion of this period as a period of high innovative activity. ${ }^{9}$ Mensch's (1979) listing of basic innovations for the first half of the twentieth century (Table 4-4, pages 127-128) shows that fully 24 percent of them occurred in the three years from 1934-1936, which our estimates show to be years with high positive technology shocks. For example, in 1934 alone the innovations included the diesel locomotive, fluorescent

\footnotetext{
${ }^{8}$ For a very different accounting of the shocks during the Great Depression, see the Appendix Figure, which shows the shocks estimated from the specification with the quartic trend. According to these estimates, there were mostly positive technology shocks during the Great Depression.
} 
lighting, and radar. Kleinknecht (1987) summarizes the results of several studies on major innovations (Table 3.2, page 70) by five-year periods. All of them show a huge burst of innovation in the period 1935-1939. Kleinknecht's (1987) tabulation shows that the five-year period 1935-1939 was rivaled only by 1960-64 in the number of radically new products and improvement and process innovations. According to his classification, each of these five-year periods had 14 innovations. ${ }^{10}$ Thus, our time series estimates of large positive technology shocks in the period 1934-36 is consistent with the microeconomic evidence on innovative activity.

\section{World War II}

The studies of innovation discussed above also showed the period covering WWII to be a period of relatively high innovative activity, so it is not surprising that there were many positive technology shocks during this period as well. Of course, dramatic increases in government spending were also important, and these show up as sustained highly positive series of nontechnology shocks.

\section{The Post-World War II Period}

The year 1946 had very negative technology and non-technology shocks. Both were probably related to the end of WWII. The start of the Korean War in 1950 appears to have been associated with both positive technology and non-technology shocks. The period 1960-1967 experienced a sustained string of positive technology shocks. Kleinknecht's (1979) study also shows high innovative activity during this period, with 14 innovations from 1960-1964 and 11

\footnotetext{
${ }^{9}$ The date of innovation is defined by these authors as the time when a newly discovered material or technique is first produced on a regular basis or when a market for a new product is first formed.

${ }^{10}$ These numbers were calculated as the sum of columns (2) + (4) from Kleinknecht's Table 3.2, page 70. The table covers the period 1900-1969.
} 
innovations from 1965-1969. The non-technology shocks were also mostly positive during this period, with the exception of 1967 and 1969.

1974 was a year with very negative (by post-WWII standards) technology and nontechnology shocks. This was the only recession since 1946 when both the technology and the non-technology shocks were negative.

The second half of the 1990s, which has attracted attention for its high productivity growth rates, was not marked by particularly positive technology shocks. Rather, it experienced a series of small positive technology shocks without any intervening negative technology shocks. The non-technology shocks were also uniformly positive during this period.

\section{The Changing Volatility of Shocks}

Finally, a noticeable feature of both the technology and nontechnology shocks in Figure 7 is that both series appear to have become far less volatile in the postwar era. The reduced volatility of the postwar recessions has been documented by many, including Zarnowitz and Moore (1986), Taylor (1986), and DeLong and Summers (1986). ${ }^{11}$ We carry out an F-test of equal variance between the variances of the prewar and postwar technology shocks. Given the variance of the prewar technology of 15.59 with sample size 49 , and similar figures for the postwar technology of 1.59 and 54 respectively, the value of the F-statistic is $9.81(15.59 \div 1.59)$. We compare this to a critical F-value with 49 numerator degrees of freedom and 54 denominator degrees of freedom. We reject the null of equal variance for all conventional values of the Fstatistics which implies that the postwar technology is indeed (significantly) less volatile than the prewar technology.

\footnotetext{
${ }^{11}$ More recently papers such as McConnell and Perez-Quiros (2000), Blanchard and Simon (2001) and Stock and Watson (2002) have documented a decline in output volatility post 1984.
} 
The results are similar for the nontechnology shock, whose variance falls from 14.36 in the prewar period to 3.01 in the postwar period. An F-test of equal variance yields an F-statistic of 4.77. With the same sample sizes as above we reject the null of equal variances of the nontechnology shock at all conventional levels of significance.

Thus, according to these estimates both types of shocks became significantly less volatile in the postwar period. A comparison of the numbers, however, indicates that the volatility of the technology shocks fell by even more than the volatility of the non-technology shocks. Thus, our results suggest that it was not improved policy alone that stabilized the U.S. economy in the postWWII period.

\section{Conclusions}

This paper has presented estimates of models with long-run restrictions on historical US data in order to study the nature and consequences of the shocks moving labor productivity, hours, and output. Following Galí (1999), we identify the technology shock to be the only shock that can have a permanent effect on labor productivity.

We developed a new demographically-adjusted measure of hours per capita and estimated the model under a variety of assumptions about the nature of hours. We compared results from models that assumed stationary hours, a quartic trend in hours, and a unit root in hours. All three specifications gave similar results for the post-WWII period, but gave different results for the pre-WWII period. Granger-causality tests on the shocks led us to conclude that the unit root specification led to the most reasonable results. According to this specification, a positive technology shock leads labor to rise in the period from 1889-1940. In contrast, the same type of shock leads labor to fall in the period from 1949-2002. 
We then investigated some of the characteristics of the shocks and their role in fluctuations. Technology shocks were much more important for fluctuations in the pre-WWII period than in the post-WWII period. The periods with the most notable series of positive technology shocks were the late teens to the mid-20s, 1934-1936, and the early 1960s. The Great Depression was a period characterized by very negative technology and non-technology shocks. Finally, both types of shocks are responsible for the reduction in the variance of output in the post-WWII period, suggesting that better policy is not the sole cause of the reduction of GDP volatility in the post-WWII era. 


\section{References}

Richard Anderson, "Some Tables of Historical US Currency and Monetary Aggregates Data," March 2002 manuscript

Balke, Nathan S. and Robert J. Gordon, "The Estimation of Prewar Gross National Product: Methodology and New Evidence," Journal of Political Economy, 97 (February 1989): $38-92$.

Basu, Susanto, Miles Kimball, and John Fernald, "Are Technology Improvements Contractionary?" NBER working paper, June 2004.

Blanchard, Olivier and Danny Quah, "The Dynamics Effects of Aggregate Demand and Supply Disturbances," American Economic Review, 79 (September 1989): 654-73.

Blanchard, O.J. and Simon, J., "The Long and Large Decline in U.S. Output Volatility," Brookings Papers on Economic Activity, 2001:1, 135 - 164

Campbell, John Y. and Pierre Perron, "Pitfalls and Opportunities: What Macroeconomists Should Know About Unit roots," NBER Macroeconomics Annual (1991), pp. 141-201

Christiano, Lawrence, Martin Eichenbaum, and Robert Vigfusson, "What Happens After a Technology Shock?” 2003 NBER working paper 9819.

Cole, Harold L. and Lee E. Ohanian, "New Deal Policies and the Persistence of the Great Depression: A General Equilibrium Analysis" February 2003 manuscript.

Costello, Donna, "A Cross-Country, Cross-Industry Comparison of Productivity Growth," Journal of Political Economy, volume 101, issue 2 (April 1993).

Delong, J. Bradford and Lawrence H. Summers, "The Changing Cyclical Variability of Economic Activity in the United States," in Robert Gordon, ed. The American Business Cycle: Continuity and Change, Chicago: NBER and University of Chicago Press, 1986.

Eckstein, Otto and Allen Sinai, "The Mechanisms of the Business Cycle in the Postwar Era," in Robert Gordon, ed. The American Business Cycle: Continuity and Change, Chicago: NBER and University of Chicago Press, 1986.

Evans, Charles L., "Productivity Shocks and Real Business Cycles," Journal of Monetary Economics 29 (April 1992): 191-208.

Feinstein, C.H., National Income, Expenditure and Output for the United Kingdom 1855-1965, Cambridge: Cambridge University Press, 1972.

Fernald, John, "Trend Breaks, Long-Run Restrictions, and the Contractionary Effects of Technology Shocks," March 2004 manuscript. 
Field, Alexander, "The Most Technologically Progressive Decade of the Century," American Economic Review 93 (September 2003): 1399-1413.

Francis, Neville and Valerie A. Ramey, "Is the Technology-Driven Real Business Cycle Hypothesis Dead? Shocks and Aggregate Fluctuations Revisited," revised working paper September 2003.

Francis, Neville R., Michael T. Owyang and Athena T. Theodorou, "The Use of Long-Run Restrictions in Identifying Technology Shocks," Federal Reserve Bank of St. Louis Review, November/December 2003, 85(6), pp. 53-66.

Friedman, Milton and Anna Schwartz, A Monetary History of the United States, 1867-1960, Princeton: Princeton University Press, 1963.

Galí, Jordi, "Technology, Employment, and the Business Cycle: Do Technology Shocks Explain Aggregate Fluctuations," American Economic Review, 89 (March 1999): 249-271.

Galí, Jordi, J. David Lopez-Salido, and Javier Valles, "Technology Shocks and Monetary Policy: Assessing the Fed's Performance," Journal of Monetary Economics 50 (2003): 723 743.

Galí, Jordi, "On the Role of Technology Shocks as a Source of Business Cycles: Some new Evidence," Journal of European Economic Association 2-3 (2004): 372 - 380.

Galí, Jordi and Pau Rabanal, "Technology Shocks and Aggregate Fluctuations: How Well does the RBC Model Fit Postwar US Data? Forthcoming 2004 NBER Macroeconomics Annual.

Gordon, Robert ed. The American Business Cycle: Continuity and Change, Chicago: NBER and University of Chicago Press, 1986.

Granger, C.W.J., "Investigating Causal Relations by Econometric Models and Cross-Spectral Models," Econometrica 37 (1969): 424-438.

King, Robert G. and Alexander Wolman, "Inflation Targeting in a St. Louis Model of the $21^{\text {st }}$ Century," Federal Reserve Bank of St. Louis Review 78 (1996), 83-107.

Kleinknecht, Alfred, Innovation Patterns in Crisis and Prosperity, London: The MacMillan Press Ltd., 1987.

Lindé, Jesper, "The Effects of Permanent Technology Shocks on Labor Productivity and Hours in the RBC Model," November 2003 manuscript. 
McConnell, M.M., and Perez-Quiros, G., "Output Fluctuations in the United States: What has Changed Since the Early 1980s?" American Economic Review, 90(5), December 2000, $1464-76$.

Mensch, Gerhard, Stalemate in Technology: Innovations Overcome the Depression, Cambridge, MA: Ballinger Publishing Company, 1979.

Mulligan, Casey, “A Century of Labor-Leisure Distortions," NBER Working Paper No. W8774 (2002).

Shapiro, Matthew D. and Mark Watson, "Sources of Business Cycle Fluctuations," NBER Macroeconomics Annual, 1988, pp. 111 - 148.

Shea, John, “What Do Technology Shocks Do?” NBER Macroeconomics Annual, 1998, pp. 275310.

Shiller, Robert J. and Pierre Perron, "Testing the Random Walk Hypothesis: Power versus Frequency of Observations," Economic Letters 18 (1985), 381 - 386.

Stock, J.H. and Watson, M.W., "Has the Business Cycle Changed and Why?" NBER Macroeconomics Annual, 2002.

Taylor, John B., "Improvements in Macroeconomic Stability: The Role of Wages and Prices," in Robert Gordon, ed. The American Business Cycle: Continuity and Change, Chicago: NBER and University of Chicago Press, 1986.

Zarnowitz, Victor and Geoffrey H. Moore, "Major Changes in Cyclical Behavior," in Robert Gordon, ed. The American Business Cycle: Continuity and Change, Chicago: NBER and University of Chicago Press, 1986. 


\section{Data Appendix}

\section{Population:}

Data Sources: 1900- 2002 data, including age breakdown, is from the U.S. Census, Statistical Abstract of the United States: 2003, Table HS-3 and Economic Report of the President, 2003, Table B-34. 1889-1899 on the total resident population is from Historical Statistics, Table A-119.

Series Creation: Only the resident population was available before 1939. To obtain a better estimate of the total population, we added the number of armed forces overseas during WWI. Before 1900, population by age was only available in 1890 . We interpolated by multiplying the ratio of resident population in a particular age group in 1900 to resident population (all ages) in 1900. 1900-1938: Resident population age 16+ plus armed forces overseas during WWI.

\section{School Enrollment:}

The school enrollment numbers were obtained by combining information from the Digest of Education Statistics, 2002, Historical Statistics Table H442, and Claudia Goldin "A Brief History of Education in the U.S." August 1999, NBER working paper H0119. The Digest of Education Statistics contained total enrollment figures annually from 1964 2002, and every 10 years before that. We used Goldin's and the Historical Statistics enrollment numbers for K-12 to interpolate the total enrollment numbers.

\section{Government Employment}

1889-1929 data are from Kendrick Productivity Trends in the United States, 1961, Table A-VI. Data from 1929-2002 were from BEA NIPA Tables 6.8A-D. The data were spliced using overlap data at 1929. Employment is full-time workers.

\section{Real GDP, GDP Deflator, Consumption, and Investment:}

Data Sources: Real GNP and deflator 1889-1928 from Balke and Gordon, Journal of Political Economy, 1989. Real consumption expenditures and gross private investment 1889-1928: John Kendrick, Productivity Trends in the United States, 1961, Table A-IIa. Chain-weighted GDP, consumption and investment 1929-2002: BEA NIPA from www.bea.gov.

Series Creation: The pre-1928 data were multiplied by the ratio of the BEA data in 1929 to the historical data in 1929. 
Productivity, Hours, and Output in Private Business:

Data Sources: 1889-1946: John Kendrick, Productivity Trends in the United States, 1961, Tables A-X, A-XXII, A-XXIII. 1947-2002: BLS Productivity data from www.bls.gov.

Series Creation: 1889-1946 data were multiplied by the ratio of the BLS data in 1947 to the historical data in 1947.

\section{Money:}

M2: For the period 1959-2002, we used M2 from the Board of Governors of the Federal Reserve. The earlier series are from Richard Anderson, "Some Tables of Historical US Currency and Monetary Aggregates Data," March 2002 manuscript. For 1947-1958, we use Rasche's M2 series. Because Anderson argues that Friedman and Schwartz M4 series is most comparable for the early period to M2 for the later period, we use M4 where possible, and otherwise M3. 
Table 1: ADF Unit Root Tests

Private Business Sector

(Logarithms, lags in parenthesis were chosen optimally up to $\max =4$ )

P-values for null hypothesis of a unit root

\section{A. Labor Productivity}

\begin{tabular}{|c|l|l|l|l|}
\hline & \multicolumn{5}{|c|}{ Alternative hypothesis } \\
\hline Time Period & No trend & Linear trend & Quadratic trend \\
\hline $\mathbf{1 8 8 9}-\mathbf{2 0 0 2}$ & $0.964(4)$ & $0.760 \quad(4)$ & $0.970 \quad(4)$ \\
\hline $\mathbf{1 8 8 9}-\mathbf{1 9 4 0}$ & $0.982(4)$ & $0.578 \quad(2)$ & $0.617 \quad(2)$ \\
\hline $\mathbf{1 9 4 8}-\mathbf{2 0 0 2}$ & $0.461 \quad(2)$ & $0.760 \quad(2)$ & $0.994 \quad(2)$ \\
\hline
\end{tabular}

B. Private Hours Divided by Population 16+ Years

\begin{tabular}{|l|l|l|l|l|}
\hline & \multicolumn{5}{|c|}{ Alternative hypothesis } \\
\hline Time Period & No trend & Linear trend & Quadratic trend \\
\hline $\mathbf{1 8 8 9}-\mathbf{2 0 0 2}$ & $0.625(3)$ & $0.512 \quad(3)$ & $0.353 \quad(3)$ \\
\hline $\mathbf{1 8 8 9}-\mathbf{1 9 4 0}$ & $0.875(2)$ & $0.677 \quad(2)$ & $0.009 \quad(4)$ \\
\hline $\mathbf{1 9 4 8}-\mathbf{2 0 0 2}$ & $0.183(4)$ & $0.825 \quad(4)$ & $0.270 \quad(3)$ \\
\hline
\end{tabular}

\section{Private Hours Divided by Adjusted Population}

\begin{tabular}{|c|l|l|l|l|}
\hline & \multicolumn{5}{|c|}{ Alternative hypothesis } \\
\hline Time Period & No trend & Linear trend & Quadratic trend \\
\hline $\mathbf{1 8 8 9}-\mathbf{2 0 0 2}$ & $0.057(3)$ & $0.127 \quad(3)$ & $0.108 \quad(3)$ \\
\hline $\mathbf{1 8 8 9}-\mathbf{1 9 4 0}$ & $0.575(2)$ & $0.498 \quad(2)$ & $0.040 \quad(4)$ \\
\hline $\mathbf{1 9 4 8}-\mathbf{2 0 0 2}$ & $0.420(4)$ & $0.266 \quad(3)$ & $0.460 \quad(3)$ \\
\hline
\end{tabular}


Table 2. Correlation of Technology Shocks Across Specifications

Pre-WWII: $1892-1940$

\begin{tabular}{|l|c|c|c|}
\hline Specification & Levels & Deterministic Trend & Unit Root \\
\hline Levels & 1.00 & & \\
\hline Deterministic Trend & 0.95 & 1.00 & 1.00 \\
\hline Unit root & 0.12 & 0.42 & \\
\hline
\end{tabular}

Post-WWII: $1949-2002$

\begin{tabular}{|l|c|c|c|}
\hline Specification & Levels & Deterministic Trend & Unit Root \\
\hline Levels & 1.00 & & \\
\hline Deterministic Trend & 0.98 & 1.00 & \\
\hline Unit root & 0.87 & 0.92 & 1.00 \\
\hline
\end{tabular}

Addendum:

Standard deviation of the technology shock relative to the non-technology shock

\begin{tabular}{|l|l|l|l|}
\hline & Levels & Deterministic Trend & Unit Root \\
\hline $\mathbf{1 8 9 2}-\mathbf{1 9 4 0}$ & 1.6 & 0.96 & 1.0 \\
\hline $\mathbf{1 9 4 9}-\mathbf{2 0 0 2}$ & 0.57 & 0.69 & 0.73 \\
\hline
\end{tabular}


Table 3: Granger Causality Tests

\section{A. Dependent Variable: Identified Technology Shocks}

\begin{tabular}{|l|l|l|l|l|}
\hline \multicolumn{1}{|c|}{ Model } & \multicolumn{2}{c|}{ Prewar: 1892-1940 } & \multicolumn{2}{c|}{ Postwar: 1949-2002 } \\
\hline & P-value on F-test & R-squared & P-value on F-test & R-squared \\
\hline Levels & 0.001 & 0.392 & 0.105 & 0.193 \\
\hline Detrended & 0.005 & 0.342 & 0.119 & 0.187 \\
\hline Unit root & 0.210 & 0.174 & 0.174 & 0.168 \\
\hline
\end{tabular}

\section{B. Dependent Variable: Identified Non-Technology Shocks}

\begin{tabular}{|l|l|l|l|l|}
\hline \multicolumn{1}{|c|}{ Model } & \multicolumn{2}{c|}{ Prewar: 1892-1940 } & \multicolumn{2}{c|}{ Postwar: 1949-2002 } \\
\hline & P-value on F-test & R-squared & P-value on F-test & R-squared \\
\hline Levels & 0.181 & 0.183 & 0.085 & 0.203 \\
\hline Detrended & 0.093 & 0.219 & 0.162 & 0.172 \\
\hline Unit root & 0.002 & 0.384 & 0.139 & 0.179 \\
\hline
\end{tabular}

The tests are based on a regression of the shock on a constant and two lags each of the growth rates of per capita government spending, per capita money, and GDP deflator. The null hypothesis is that all coefficients on these variables (excluding the constant) are zero. 
Table 4. Variance Decomposition: Unit Root Specification

Percent of Forecast Variance Explained by Technology Shocks

\begin{tabular}{|c|c|c|c|c|c|c|}
\hline & \multicolumn{3}{|c|}{$1892-\mathbf{1 9 4 0}$} & \multicolumn{3}{c|}{$1949-\mathbf{2 0 0 2}$} \\
\hline $\begin{array}{c}\text { Horizon } \\
\text { (in years) }\end{array}$ & Productivity & Hours & Output & Productivity & Hours & Output \\
\hline $\mathbf{1}$ & 95 & 33 & 80 & 65 & 25 & 0 \\
\hline $\mathbf{2}$ & 96 & 40 & 73 & 88 & 18 & 5 \\
\hline $\mathbf{3}$ & 96 & 44 & 72 & 94 & 15 & 22 \\
\hline $\mathbf{4}$ & 97 & 44 & 72 & 96 & 12 & 37 \\
\hline $\mathbf{5}$ & 98 & 45 & 72 & 97 & 11 & 45 \\
\hline $\mathbf{1 0}$ & 99 & 46 & 71 & 99 & 7 & 64 \\
\hline $\mathbf{2 0}$ & 99 & 46 & 71 & 100 & 4 & 72 \\
\hline
\end{tabular}


Figure 1A. Labor Productivity in the Private Sector

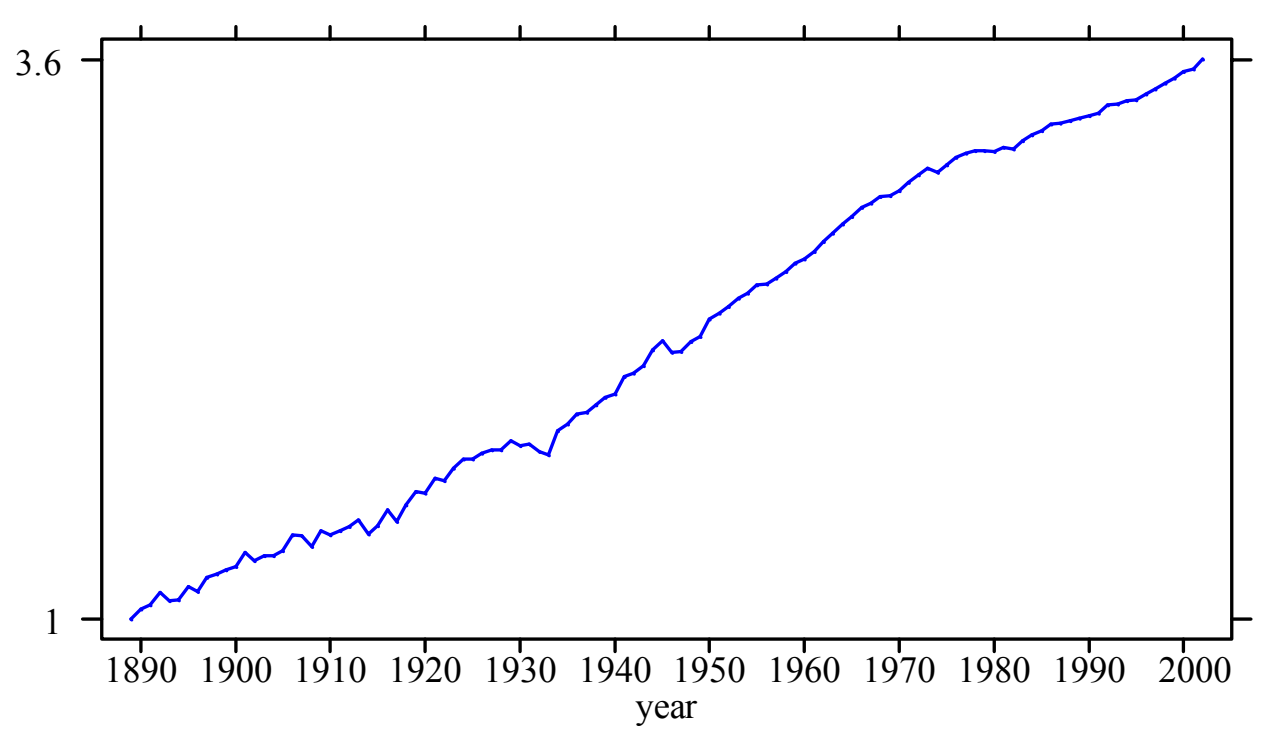

Figure 1B. Growth Rate of Labor Productivity in the Private Sector

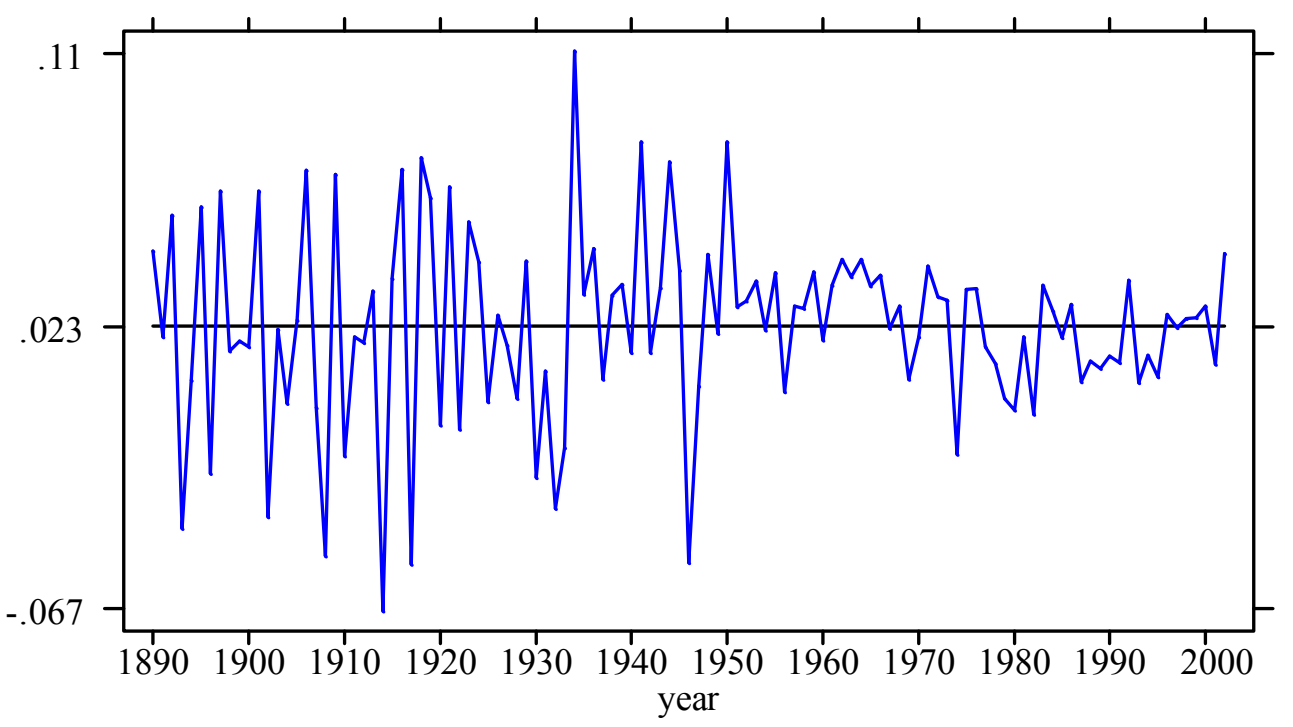


Figure 2A. Private Hours Divided by Population 16+ Years

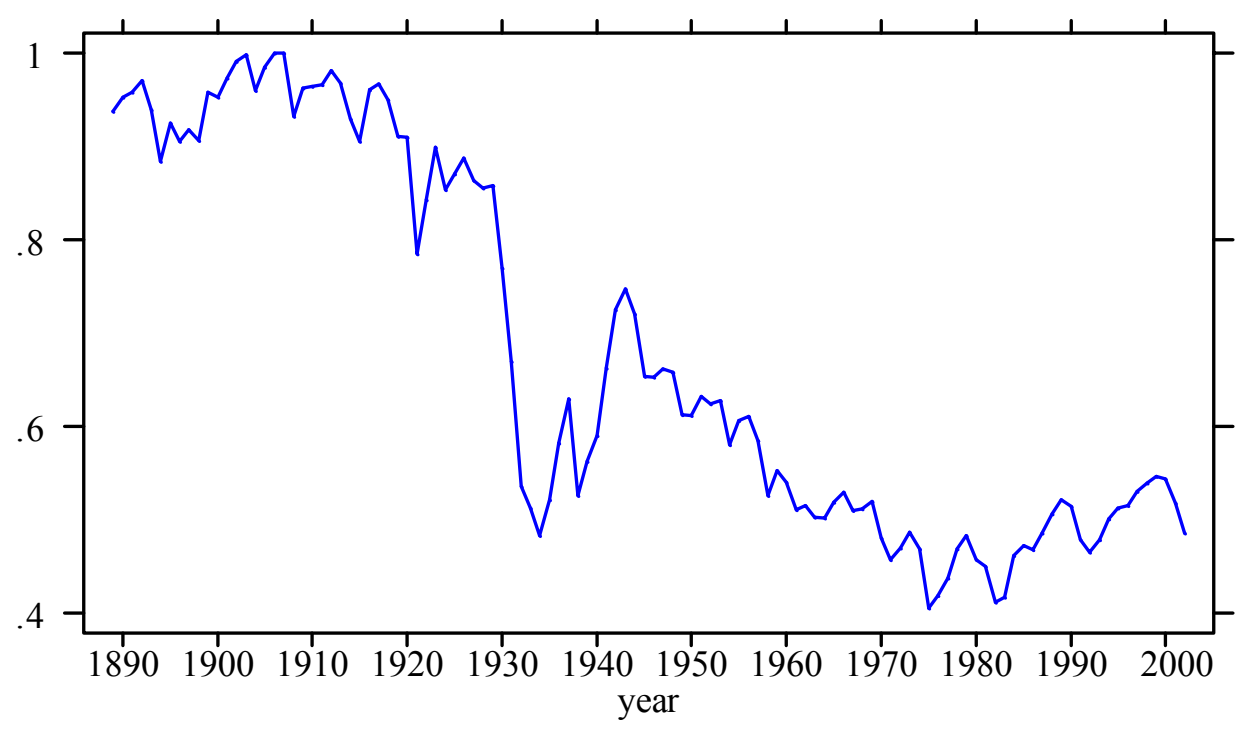

Figure 2B. Private Hours Divided by Demographically-Adjusted Population

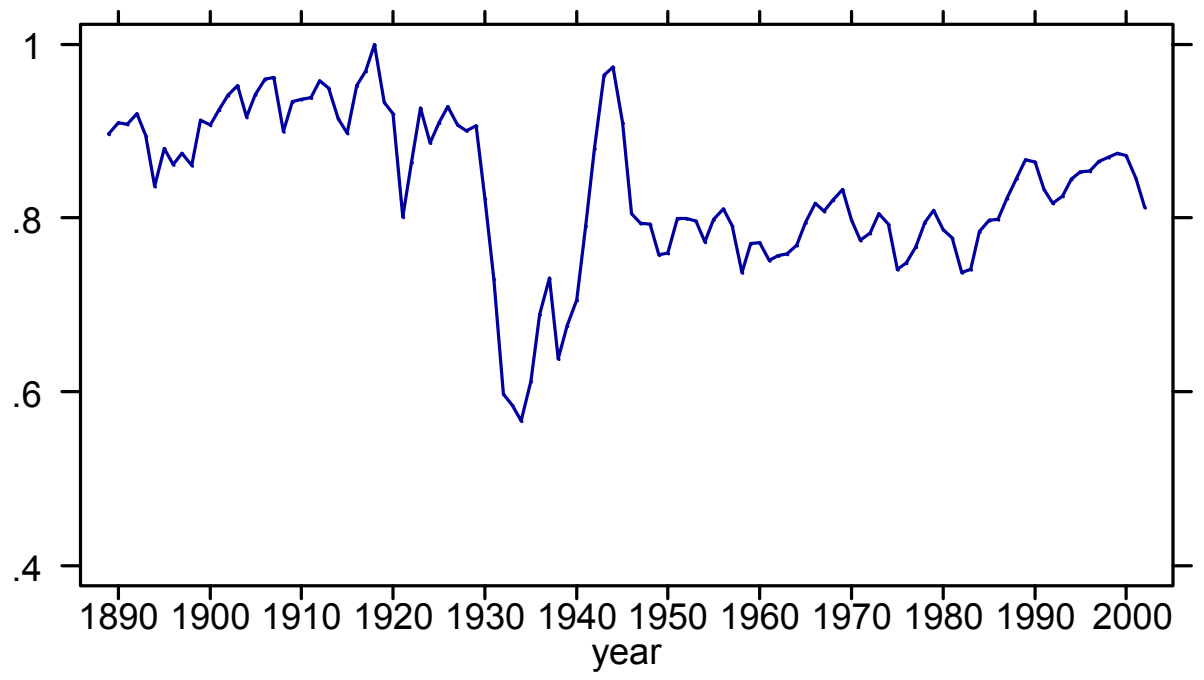




\section{Figure 3. Sub-Groups as a Fraction of Total Population}
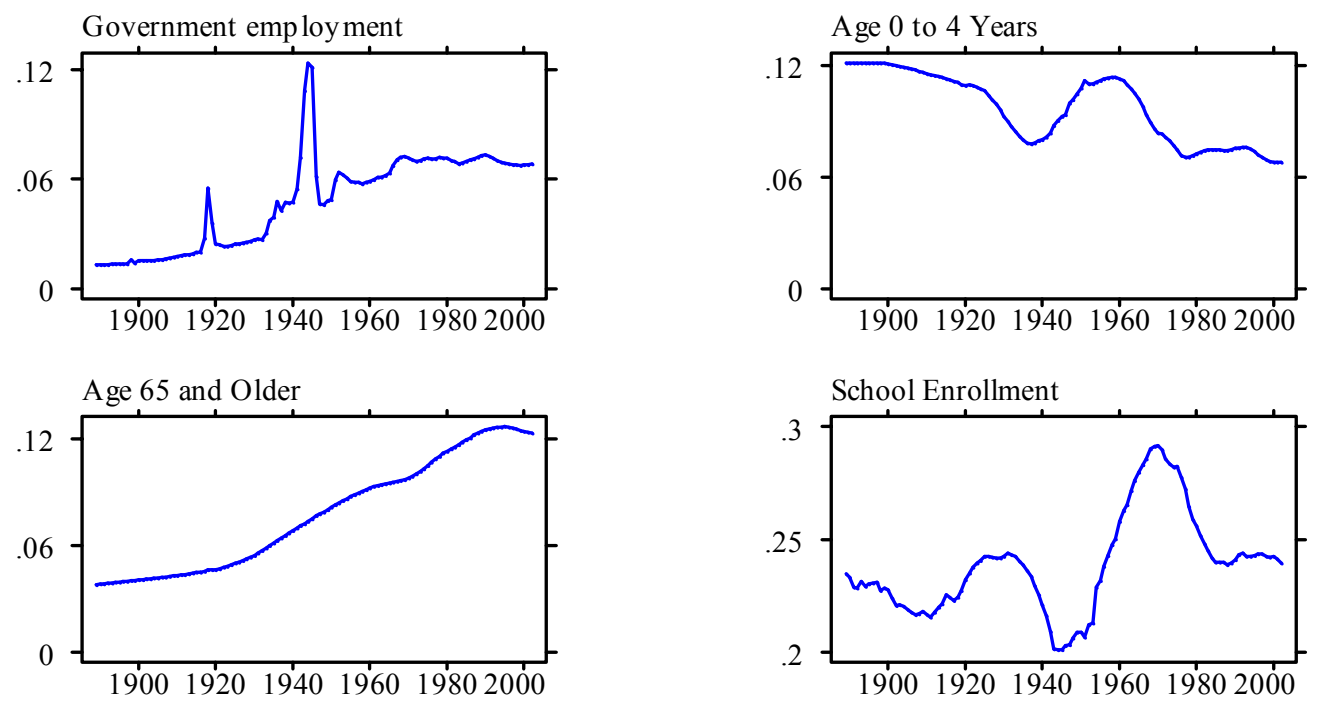
Figure 4. Quartic Detrending of Demographically Adjusted Hours

\section{A. Quartic Trend}

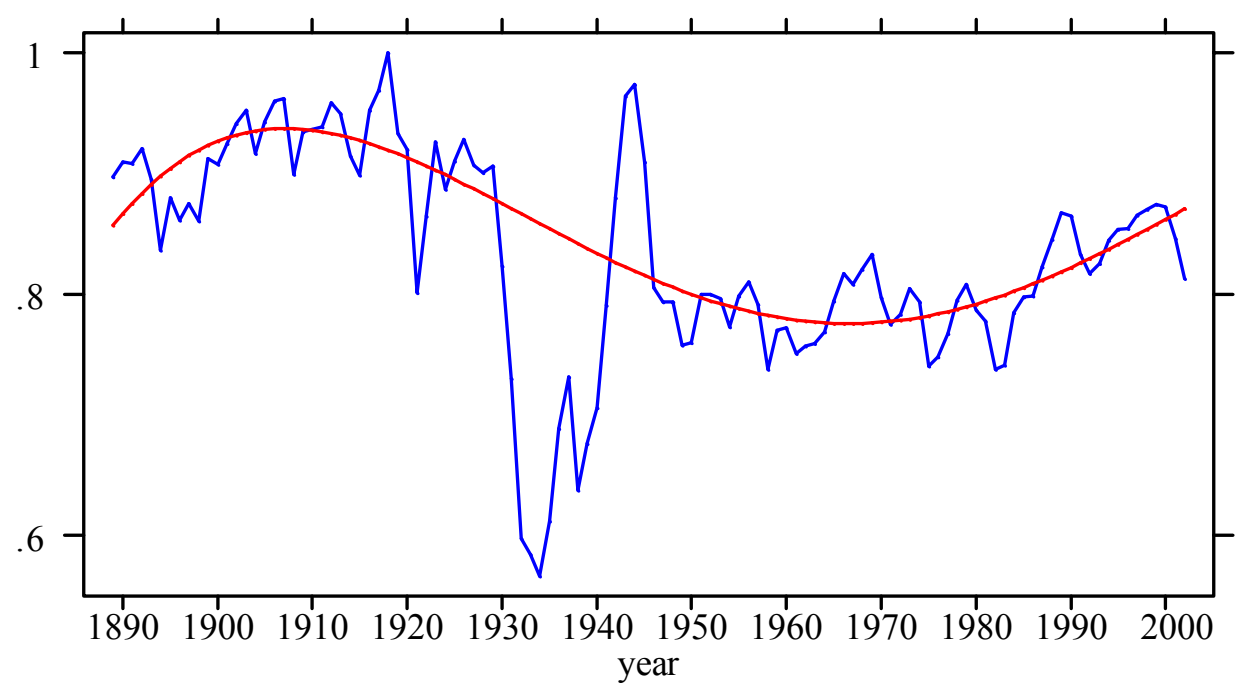

B. Detrended Hours

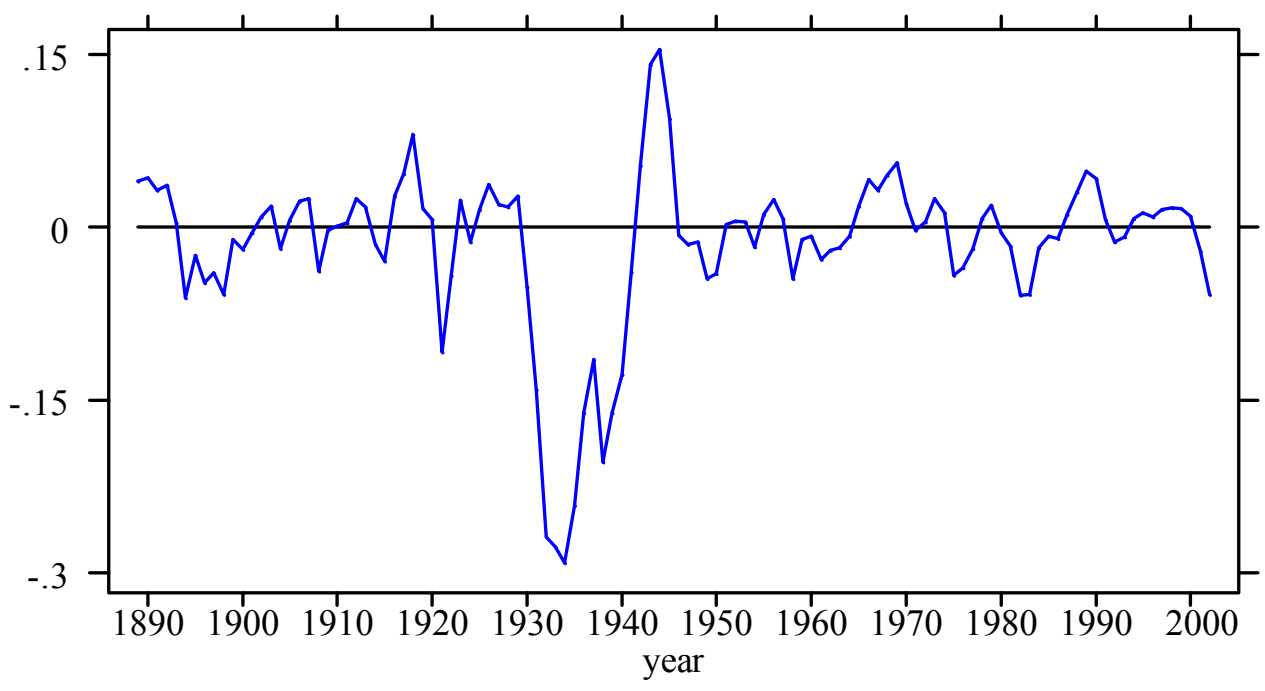


Figure 5. Impulse Response Functions: 1892-2002

(Blue thin line: hours in levels; Red thick line: detrended; Green dashed: unit root) (Circles indicate significance at 10 percent level)

\section{Unit Technology Shock}
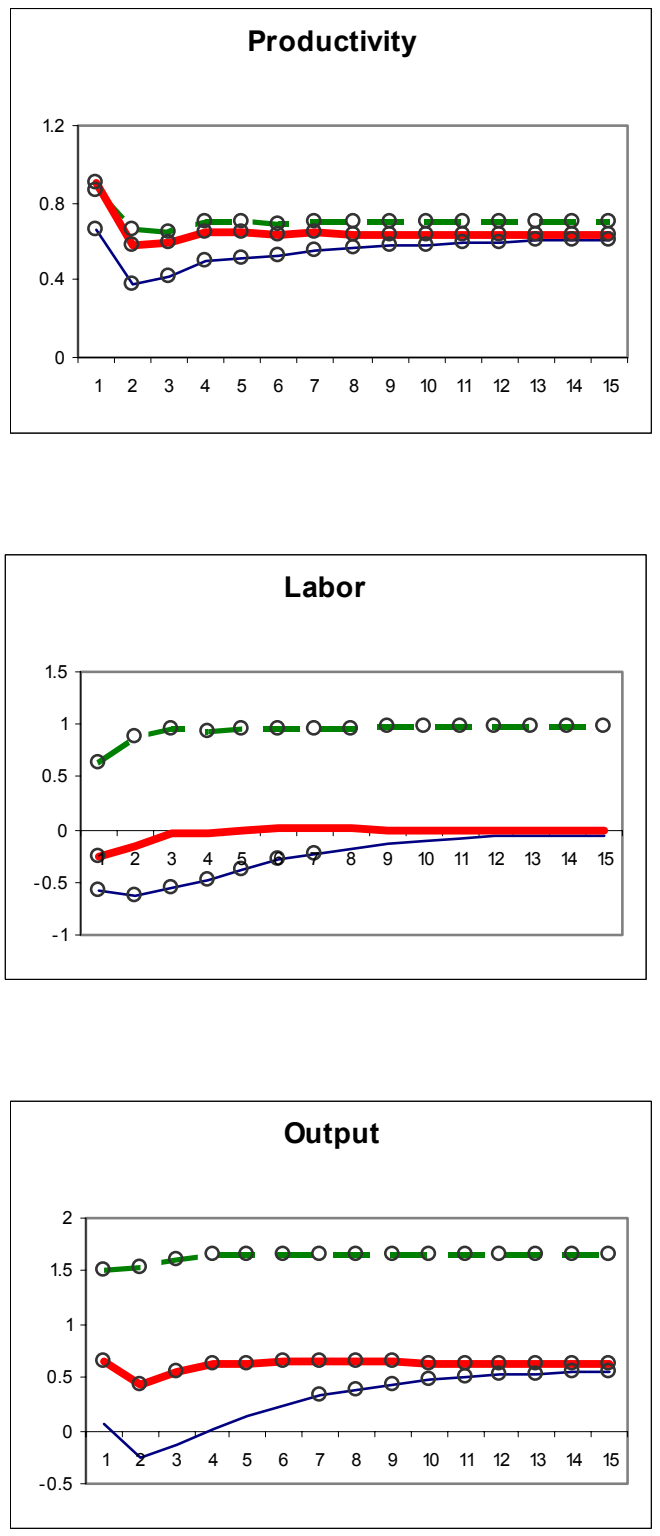

\section{Unit Non-technology Shock}
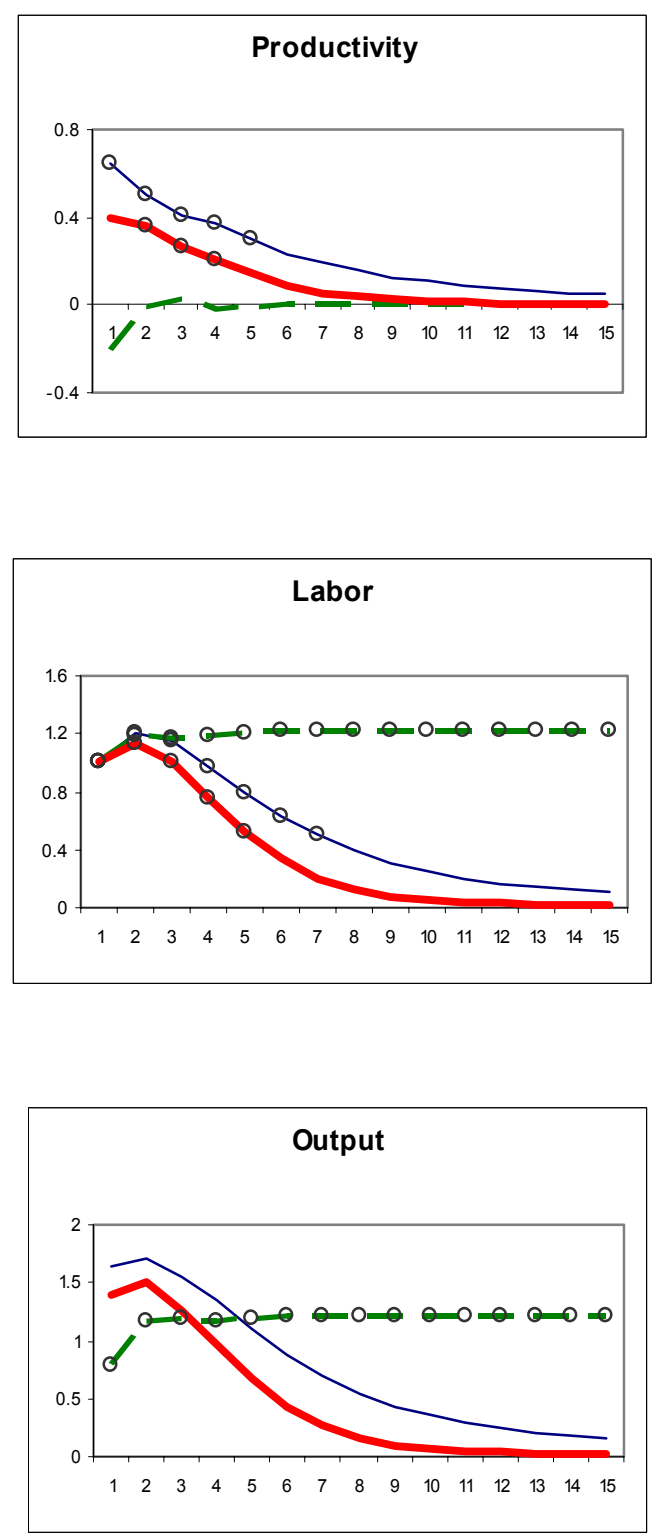
Figure 6A. Impulse Response Functions: Effects of a Technology Shock (Blue thin line: hours in levels; Red thick line: detrended; Green dashed: unit root) (Circles indicate significance at 10 percent level)

$1892-1940$

$1949-2002$
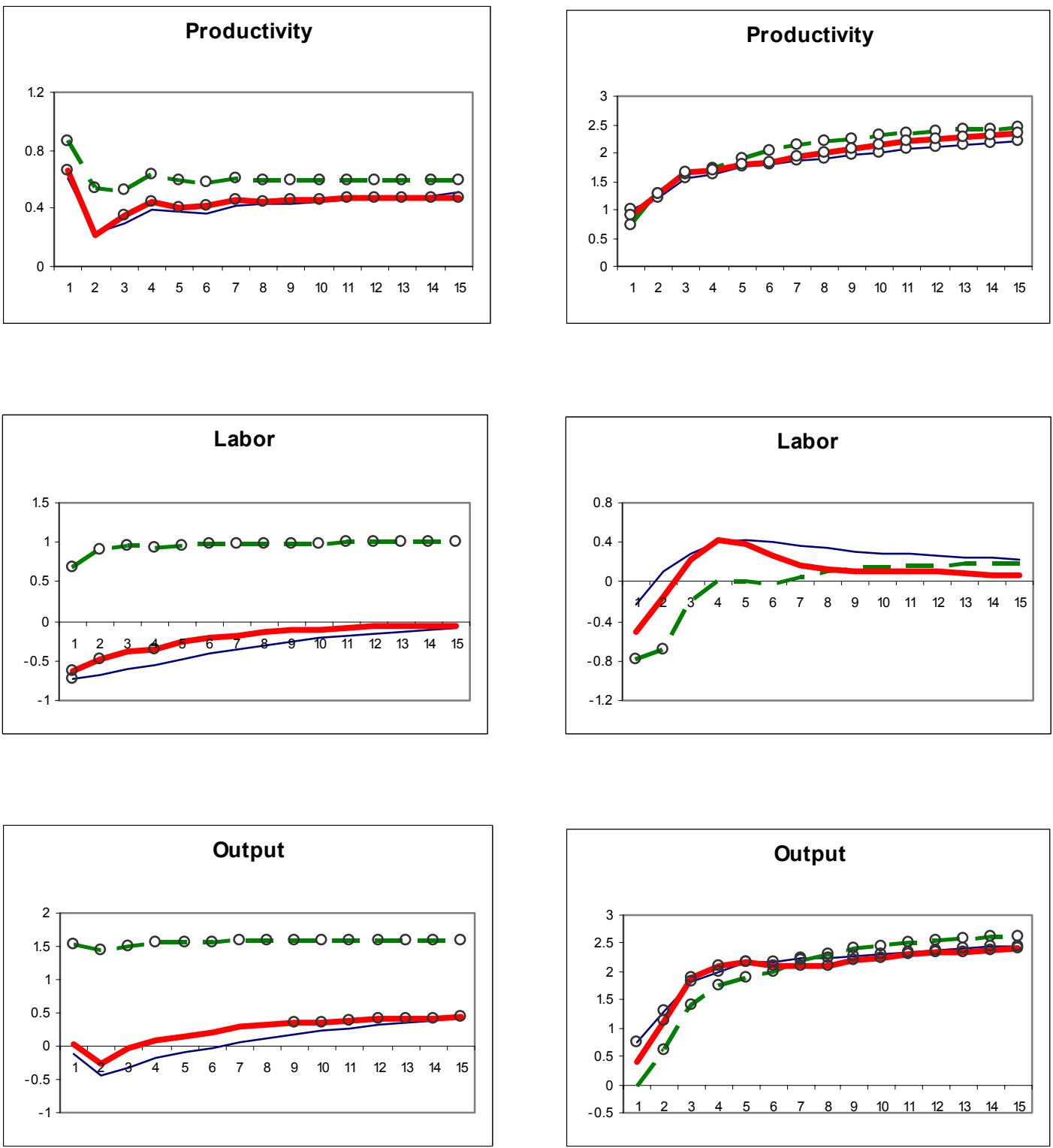
Figure 6B. Impulse Response Functions: Effects of a Non-Technology Shock (Blue thin line: hours in levels; Red thick line: detrended; Green dashed: unit root)

(Circles indicate significance at 10 percent level)

$1892-1940$
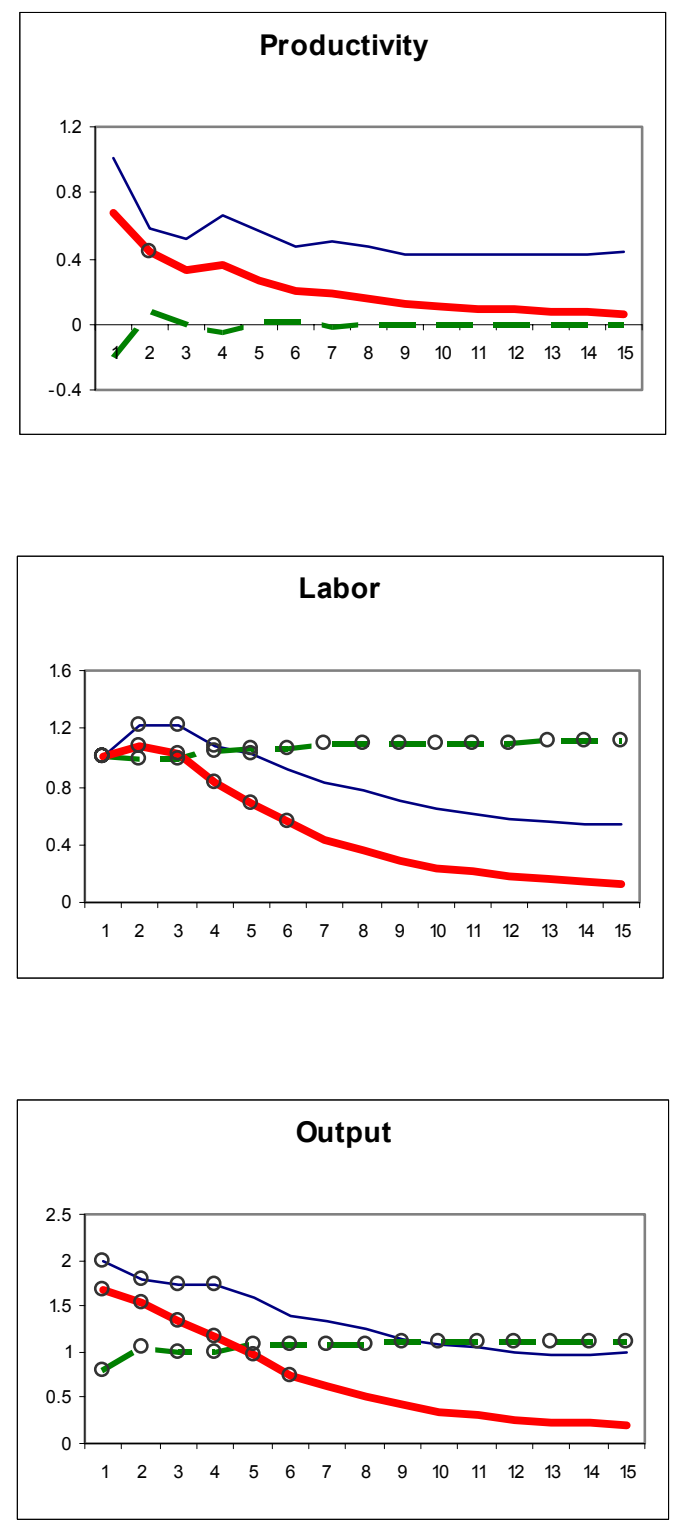

$1949-2002$
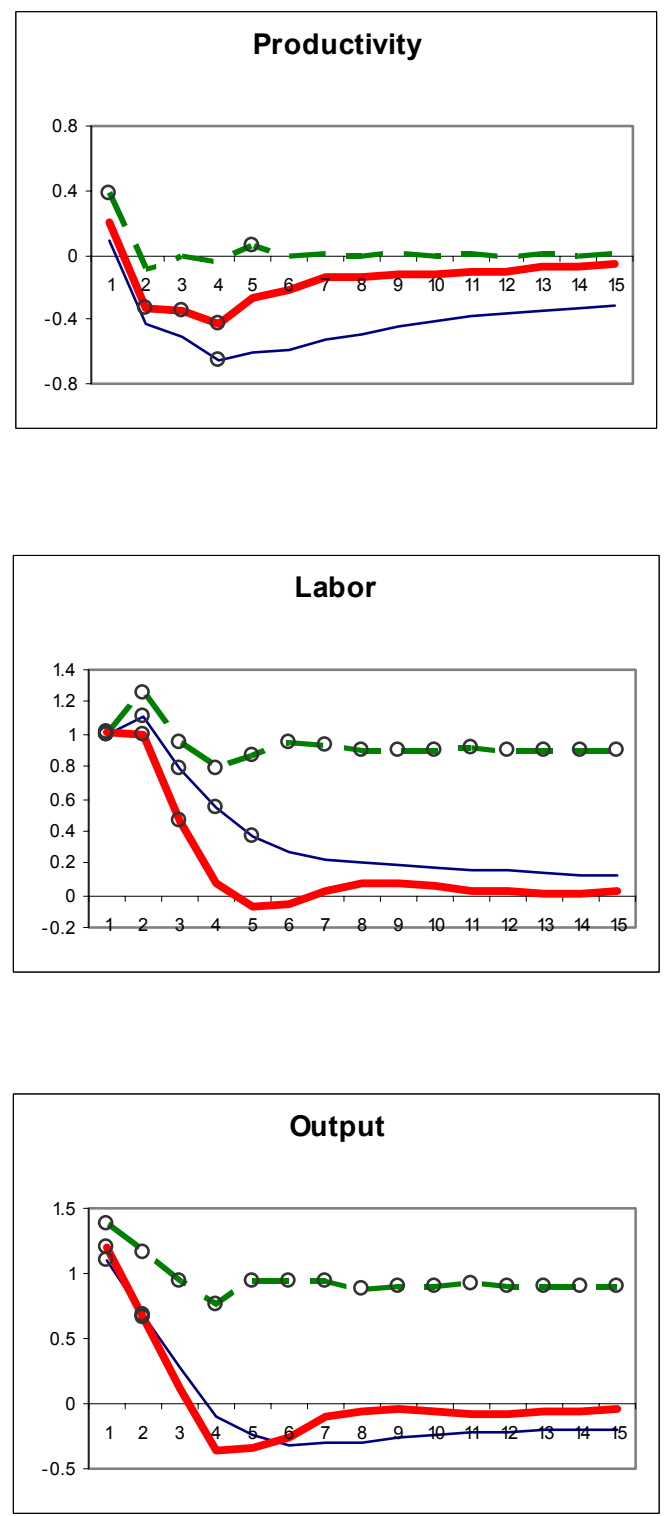
Figure 7: Plots of implied shocks from Unit Root specification (Based on sub-sample estimates; shaded areas represent NBER recession dates)

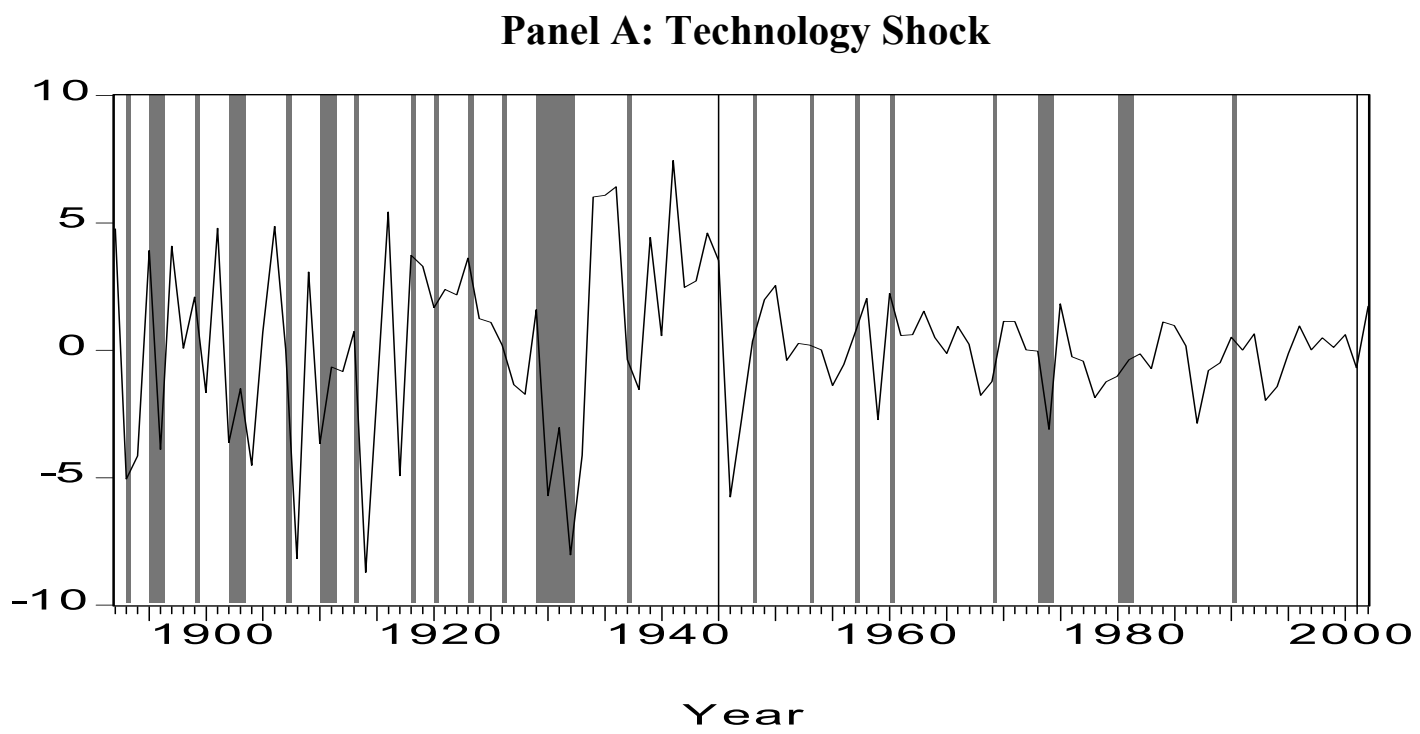

Panel B: Nontechnology Shock

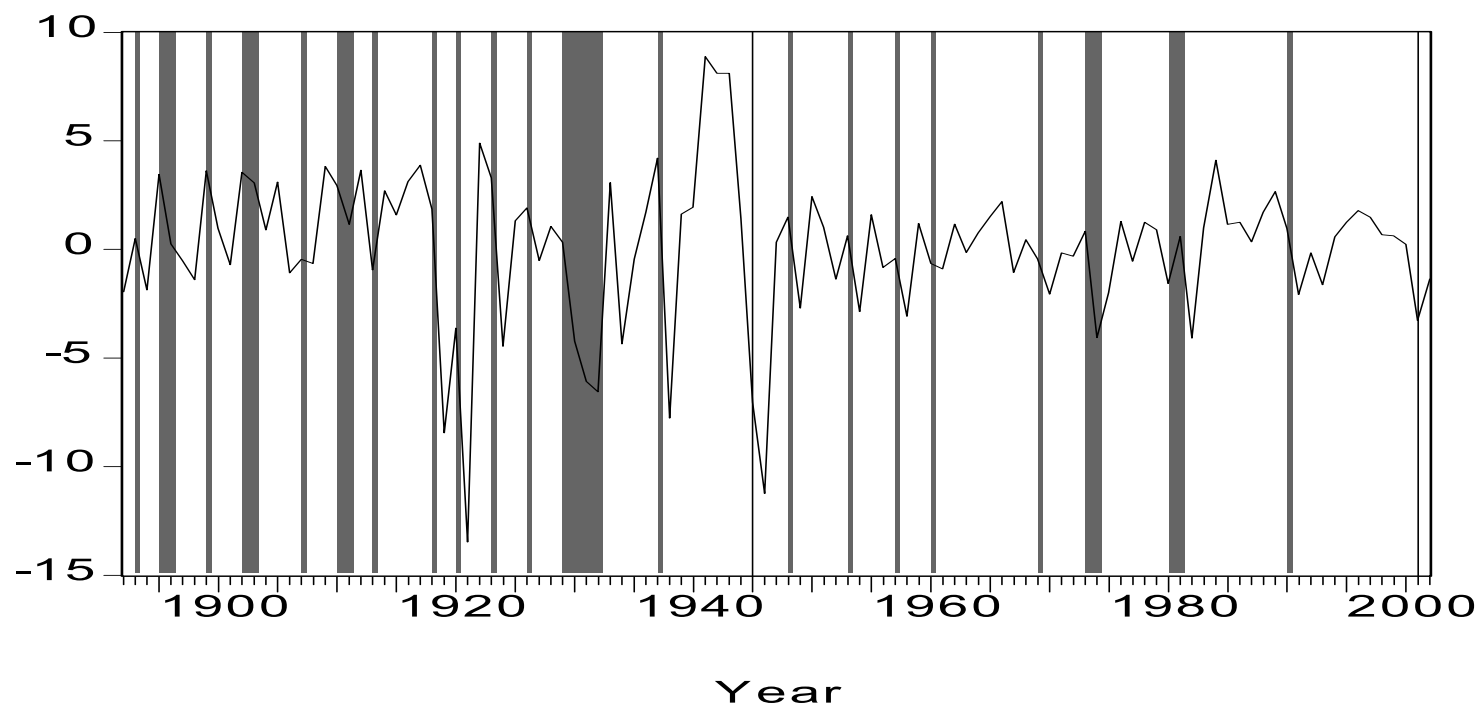




\section{Appendix Tables and Figures}

\section{Appendix Table: Variance Decomposition: Quartic Trend Specification}

Percent of Forecast Variance Explained by Technology Shocks

\begin{tabular}{|c|c|c|c|c|c|c|}
\hline & \multicolumn{3}{|c|}{$1892-\mathbf{1 9 4 0}$} & \multicolumn{3}{c|}{ 1949-2002 } \\
\hline $\begin{array}{c}\text { Horizon } \\
\text { (in years) }\end{array}$ & Productivity & Hours & Output & Productivity & Hours & Output \\
\hline $\mathbf{1}$ & 40 & 26 & 0 & 90 & 10 & 5 \\
\hline $\mathbf{2}$ & 33 & 21 & 2 & 88 & 6 & 26 \\
\hline $\mathbf{3}$ & 36 & 18 & 1 & 90 & 6 & 55 \\
\hline $\mathbf{4}$ & 40 & 18 & 1 & 89 & 10 & 68 \\
\hline $\mathbf{5}$ & 44 & 18 & 1 & 91 & 12 & 75 \\
\hline $\mathbf{1 0}$ & 62 & 17 & 5 & 96 & 14 & 88 \\
\hline $\mathbf{2 0}$ & 79 & 17 & 20 & 98 & 14 & 95 \\
\hline
\end{tabular}


Appendix Figure: Plots of implied shocks from Quartic Trend specification (shaded areas represent NBER recession dates)

Panel A: Technology Shock

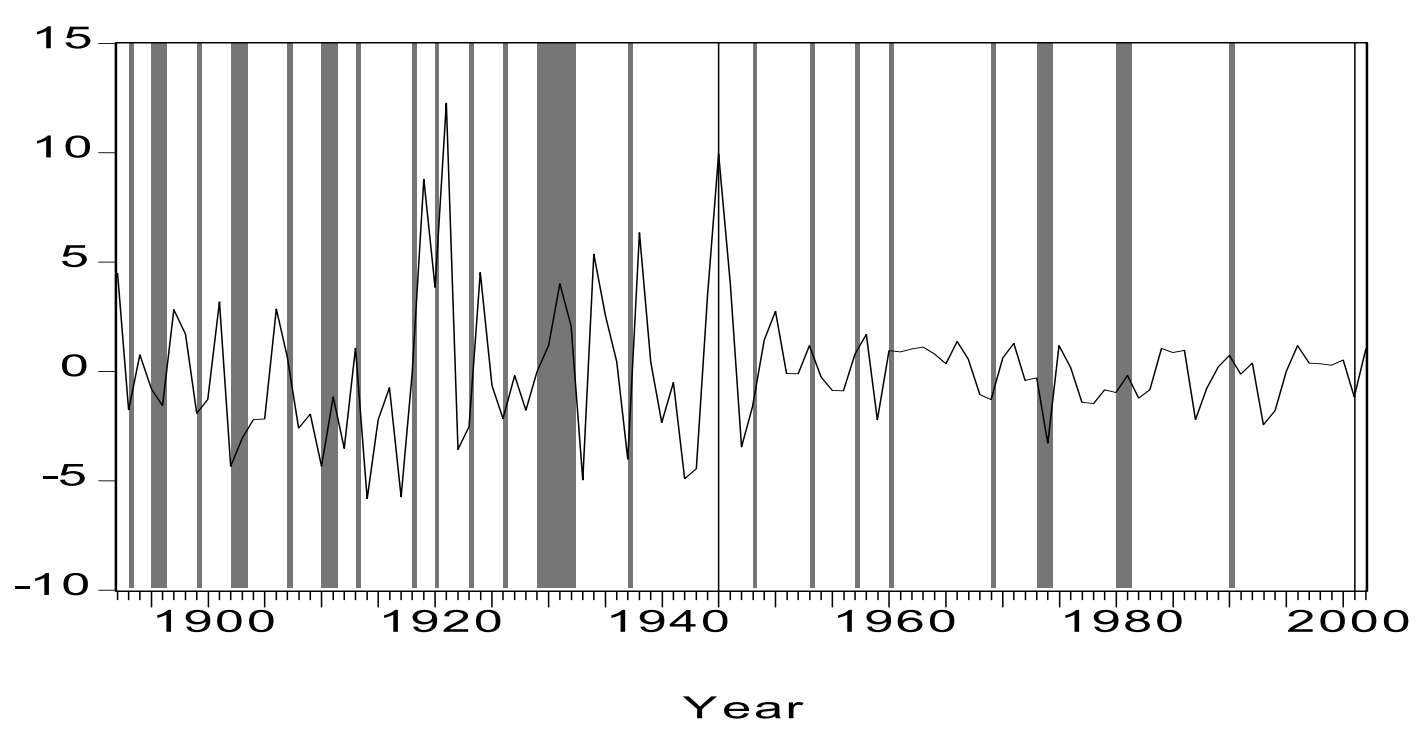

Panel B: Nontechnology Shock

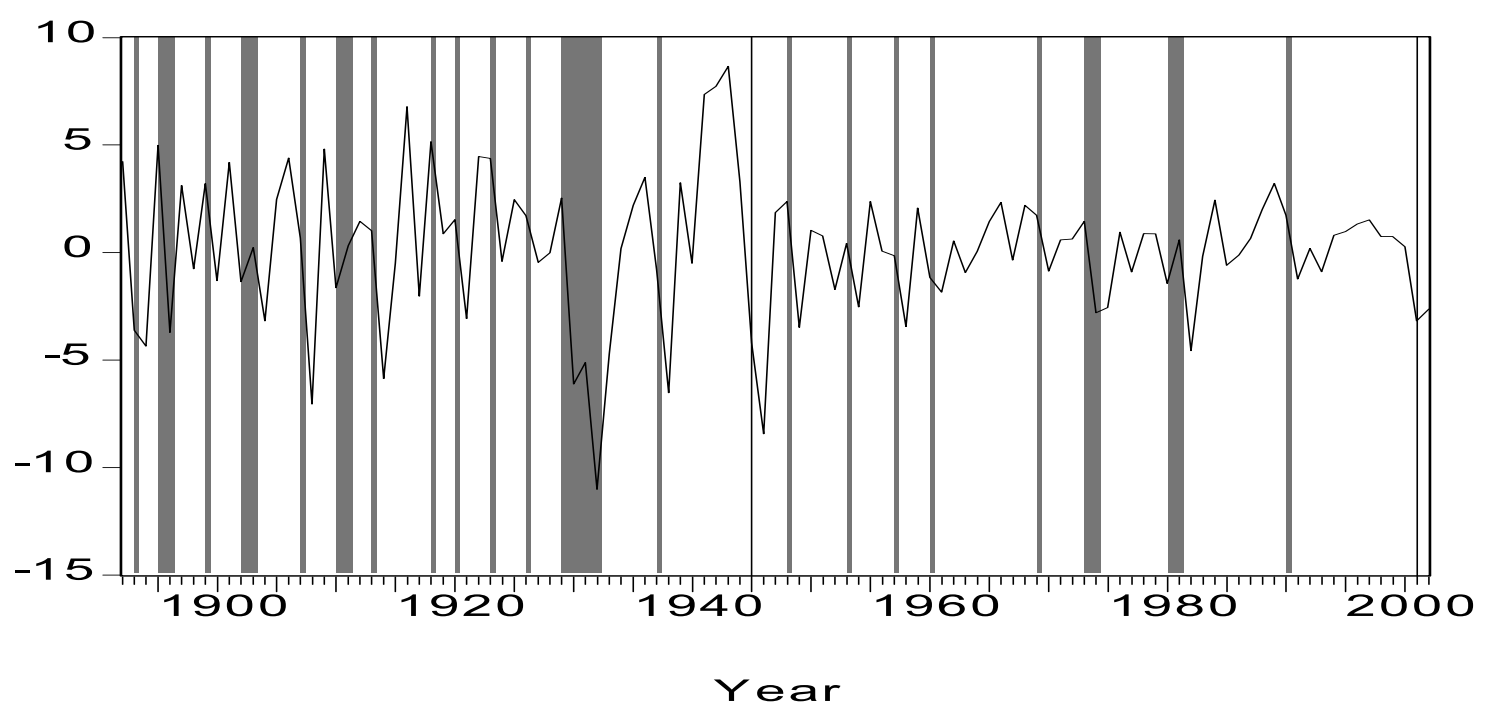

